PAEDAGOGIA ChristianA

2/24 (2009) - ISSN 1505-6872

Edyta Wolter*

Warszawa

\title{
Podmiotowość jako kategoria pedagogiczna
}

Kategoria ${ }^{1}$ jest pojęciem ogólnym, które służy do grupowania mniej ogólnych pojęć - poszczególnych aspektów rzeczywistości. Wyróżnia się kategorie archiwalne, leksykalne, semantyczne, społeczne itd. Ponieważ pedagogika jako dyscyplina naukowa bada, opisuje, pomaga zrozumieć świat i jest nauką inspirująca oświatę $^{2}$ - do podstawowych kategorii pojęciowych pedagogiki ${ }^{3}$ zaliczono: odpowiedzialność, podmiotowość, samorealizację, tolerancję, twórczość, wyobraźnię.

Podmiotem jest jednostka ludzka, która ma świadomość siebie, poczucie odrębności „we wszystkich aktach ludzkich (materialnych, cielesnych, duchowych, poznawczych, decyzyjnych, twórczych)"4 oraz samoprzekształcania się w procesie przechodzenia od epoki nowoczesnej do epoki ponowoczesnej; od formacji społeczeństwa industrialnego i ortodoksyjnego ujmowania edukacji do społeczeństwa wiedzy, akceptacji heterogeniczności; poszerzania się przedmiotu badań pedagogiki - także w zakresie pedagogii (społecznej praktyki edukacyj$\left.n^{5} j^{5}\right)-w$,cywilizacji globalnej”, która nie jest systemem liniowym ${ }^{6}$.

* Dr Edyta Wolter, adiunkt w Katedrze Pedagogiki Społecznej i Pedagogiki Pracy na Uniwersytecie Kardynała Stefana Wyszyńskiego w Warszawie.

${ }^{1}$ Stownik terminologiczny informacji naukowej, (przedmowa M. Dembińska), Wrocław-Warszawa-Kraków-Gdańsk 1979, s. 62-63.

${ }^{2}$ T. Lewowicki, O tożsamości, kondycji i powinnościach pedagogiki, Warszawa-Radom 2007, s. 238-239.

${ }^{3}$ B. Milerski, B. Śliwerski (red.), Pedagogika PWN. Leksykon, Warszawa 2000, s. 95-96.

${ }^{4}$ P. Rabaczyński, Podmiotowość, w: C. Rogowski (red.), Leksykon pedagogiki religii, Warszawa 2007, s. 581. Por. Z. Struzik, Program wychowawczy oparty na wartościach, w: J. Placha, W. Sroczyński, E. Wolter (red.), Nauczanie Jana Pawła II a wspótczesna aksjologia pedagogiczna, Warszawa 2008, s. $152-153$.

${ }_{5}^{5}$ T. Hejnicka-Bezwińska, Pedagogika ogólna. Pedagogika wobec wspótczesności, Warszawa 2008, s. 68-69.

${ }^{6}$ J. Rudniański, Wychowanie i diabeł entropii, w: I. Wojnar, Edukacyjna kultura przyszłości. 
Pojęcie podmiotowości ${ }^{7}$ jest rozważane, analizowane, wyjaśniane w aspektach: filozoficznym (jako przeciwieństwo reifikacji), socjologicznym (w kontekście zmian społecznych w strukturze społecznej), psychologicznym (świadomość autonomii duchowej), pedagogicznym (podmiot wychowujący, podmiot wychowywany). Podmiotowość dotyczy zarówno procesu wychowania (zasada podmiotowości), jak i celu wychowania. Przy czym kształtowanie orientacji podmiotowej (poczucie podmiotowości) jako zadanie dydaktyczno-wychowawcze jest procesem złożonym i długotrwałym, w którym podmiotami (partnerami kontaktu wychowawczego) są nauczyciele-wychowawcy oraz uczniowie-wychowankowie.

W społeczeństwie ponowoczesnym wychowanie podmiotowe homo huma$n u s^{8}$,wiąże się w sposób zasadniczy z szansą człowieka «możliwego», warunkami jego rozwoju i twórczego działania, zarówno w wyniku intencjonalnych procesów edukacyjnych, jak osobistej samoedukacji" ${ }^{9} \mathrm{w}$ dojrzewaniu do wartościowego człowieczeństwa ${ }^{10}$ (istotą jest dusza człowieka ${ }^{11}$ ) i szczęścia, polegającego na zaspakajaniu potrzeb umysłowych, artystycznych, moralnych, religijnych, społecznych ${ }^{12}$.

W paradygmacie edukacji podmiotowej ${ }^{13}$ istotny jest człowiek jako osoba. W tym miejscu warto przypomnieć o nurtach pedagogicznych akcentujących autonomiczną wartość osoby ludzkiej, określanych mianem ,pedagogika ducha” (pedagogika humanistyczna), takich jak: chrześcijańska pedagogika personalnoegzystencjalna (J. Tarnowski), pedagogika niedyrektywna (C. R. Rogers), pedagogika Gestalt (integrująca pod tą nazwą wiedzę kilku nurtów w naukach humanistycznych: psychologię humanistyczną, egzystencjalizm i fenomenologię, pedagogikę holistyczną, psychosocjoterapię, oświatę dorosłych), pedagogia wychowania integralnego (H. Dauber, N. Postman), pedagogika radykalnego humanizmu (E. Fromm) ${ }^{14}$, które nawiązują do podstawowych przesłanek dziedzictwa

Prace studyjne Zespotu Edukacji i Kultury Komitetu Prognoz „,Polska 2000 Plus” przy Prezydium PAN, Warszawa 2006, s. 232.

${ }^{7}$ E. Kubiak-Jurecka, A. Molesztak, Podmiotowość i podmioty wychowania, w: A. Tchorzewski (red.), Wychowanie w kontekście teoretycznym, Bydgoszcz 1997, s. 51-66.

${ }^{8}$ W XV i XVI wieku - w kulturze Renesansu humanitatis utożsamiano z godnością osobista, poczuciem sprawiedliwości, wykształceniem, łagodnością, tolerancją, umiarem, opanowaniem, poczuciem taktu, szczerością, życzliwością, pogodą wewnętrzną i kulturą zewnętrzną. Zob. B. Leśnodorski, Humanistyka i humanizm - nauka czy postawa, w: I. Wojnar, Edukacyjna, s. 143.

${ }^{9}$ I. Wojnar, Aktualne procesy edukacji i kultury w Polsce i na świecie, w: I. Wojnar, J. Kubin (red.), Edukacja wobec wyznań XXI wieku, Komitet Prognoz „Polska w XXI wieku” przy Prezydium PAN, Warszawa 1997, s. 30.

${ }^{10}$ J. Szczepański, Sprawy ludzkie, Warszawa 1984, s. 341.

${ }^{11}$ B. Suchodolski, Kim jest człowiek?, Warszawa 1985, s. 80.

12 W. Tatarkiewicz, O szczęściu, Warszawa 2008, s. 55.

${ }^{13}$ T. Lewowicki, Przemiany oświaty, Szkice o ideach i praktyce edukacyjnej, Warszawa 1997, s. 58.

${ }^{14}$ B. Śliwerski, Wspótczesne teorie i nurty wychowania, Kraków 2005, s. 115, 155, 175, 221. 
psychologii humanistycznej. Osiagnięcia badawcze psychologii humanistycznej - szczególnie w zakresie problemów: autonomii, holistycznej koncepcji człowieka, uwzględniania osobniczego potencjału rozwojowego, także roli uczuć i subiektywnych przekonań - stanowią konstruktywne teoretyczne podłoże dla edukacji humanistycznej (podmiotowości szkoły ${ }^{15}$ ). Według Bogusława Śliwerskiego, pedagogika dziecka ${ }^{16}$ jest szczególnym prądem pedagogicznym, wpisanym w Nowe Wychowanie (progresywizm pedagogiczny, pedagogikę reformy), dzięki któremu już na przełomie XIX/XX stulecia idea podmiotowości została urzeczywistniona w praktyce edukacyjnej, także polskiej w okresie II Rzeczypospolitej $^{17}$ (mechanizm dyfuzji ${ }^{18}$ kulturowej).

Lech Witkowski podkreślił, iż, realizując w praktyce dydaktyczno-wychowawczej fenomen edukacji podmiotowej, trzeba kształtować zintegrowane ego ${ }^{19}$. Wychowanie holistyczne ${ }^{20}$ uwzględnia harmonijny rozwój fizyczny, intelektualny, społeczny, duchowy - równoległe kształtowanie umysłu, serca, ciała „wedle zrewaloryzowanego platońskiego wzorca kalokagathii" ${ }^{21}$, w związku ze środowiskiem społeczno-przyrodniczym² ${ }^{22}$ którego człowiek jest częścią, jako ,integralna całość, nierozerwalnej jedności działania, myślenia i odczuwania"23.

Jak już wspomniałam, edukacja skierowana ,ku spełnianiu się podmiotowości” stanowi implikację pedagogiki Gestalt. Według tej koncepcji człowiek jako podmiot ciała - psychiki - ducha zdobywa swoją tożsamość, dojrzewając dzięki interakcjom w środowisku społeczno-przyrodniczym, w którym nauczyciele-wychowawcy zapraszają ucznia-wychowanka do refleksyjnego uczenia się przez przeżywanie i działanie. W pedagogii wychowania integralnego człowiek jest podmiotem i bezwarunkową wartością - nie może żyć bez Boga. Rolą nauczyciela-wychowawcy jest animowanie środowiska społeczno-przyrodniczego, kreowanie sytuacji dydaktyczno-wychowawczych sprzyjających rozwojowi duchowemu ,integrowaniu logiki rozumienia z logiką serca"24.

15 W. Okoń, Dziesięć szkół alternatywnych, Warszawa 1999, s. 226-227.

16 Twórcą nazwy pajdocentryzm jest Granville Stanley Hall (1844-1924). Zob. B. Śliwerski, Pedagogika dziecka. Studium pajdocentryzmu, Gdańsk 2007, s. 26.

${ }^{17}$ F. Bereźnicki, Hasła „,nowej szkoły” w dydaktyce Drugiej Rzeczypospolitej, Toruń 1998, s. $115 \mathrm{n}$

${ }^{18}$ R. Linton, Dyfuzja, w: E. Nowicka, M. Głowacka-Grajper (red.), Świat człowieka - świat kultury. Antologia tekstów klasycznej antropologii, Warszawa 2007, s. 338-340.

19 Por. T. Lewowicki, Przemiany oświaty, s. 60.

${ }^{20}$ L. Witkowski (red.), Listy o edukacji, „Forum oświatowe” Polskiego Towarzystwa Pedagogicznego - Tom specjalny na III Ogólnopolski Zjazd Pedagogiczny, nr 2 (19), Warszawa-Toruń 1998, s. 75-76.

21 Tamże, s. 53.

22 Zob. E. Wolter, Historyczne aspekty edukacji ekologicznej w Polsce, Warszawa 2006, s. $231-242$.

${ }^{23}$ I. Wojnar, Edukacyjna, s. 98.

${ }^{24}$ B. Śliwerski, Współczesne teorie, s. 184. 
Podmiotowość człowieka jest wartością duchową, którą można badać, wyjaśniać ze względu na wymiarr ${ }^{25}$ : modalności, treści, intencji, ogólności, intensywności, uzewnętrznienia, zakresu, organizacji. System wartości inspiruje postawy, dzięki którym wartości są realizowane w praktyce edukacyjnej. Kształtowanie systemu wartości jest odpowiedzialnym zadaniem dydaktyczno-wychowawczym, gdy „twórcza mądrość i mądra twórczość" ${ }^{26}$ współistnieją w celu rozwiązywania poszczególnych sytuacji edukacyjnych. Według Zbigniewa Pietrasińskiego ${ }^{27}$, mądrość oznacza wiedzieć i wątpić, wyraża się refleksyjnym uczeniem się i świadomością ograniczeń wiedzy. Dzieła twórcze jako nowe i oryginalne wytwory podlegają obiektywnemu lub subiektywnemu wartościowaniu. Termin „twórczość" ${ }^{28}$ w szerokim znaczeniu - w odniesieniu do dziedzin kultury: naukowej, artystycznej, organizacyjnej, technicznej, politycznej, wychowawczej - zastosowano dopiero w XX wieku. Wcześniej określenie to funkcjonowało w sztuce i do XIX wieku sądzono, że jej wzorem jest natura, a twórczość artystyczna ma jedynie cel „odtwórczy”. W kulturze ponowoczesnej przyjęto, iż większość wiadomości, umiejętności, sprawności dokonuje się na podstawie wiedzy zastanej - cechą pracy twórczej jest kreatywna interpretacja. Nawet twórcy-mistrzowie przetwarzają, czerpiąc ze struktur już znanych, jako „schematy formalne”, dzięki którym mogą być zrozumiani przez swoich odbiorców. Pracują w celu doskonalenia wiedzy, którą posługiwano się w przeszłości i której doświadcza także „teraźniejszość” - jak to Ludwik Krzywicki ujął - „otacza nas zewsząd przeszłość!"29. Chodzi o to, aby nowe jakości dojrzewały do niepowtarzalnych kreacji - bogactwa sensów - syntezy wielości znaczeń, która jest cechą społeczeństwa pluralistycznego. Tak więc mądra twórczość jest współtwórczością uczciwości intelektualnej, która nie pozwala na upokarzanie, wyrządzanie szkód psychicznych. Zdaniem Krzysztofa Konarzewskiego ${ }^{30}$, badacz ma prawo stosować tylko takie metody, które samorzutnie mogłyby się pojawić w życiu osób badanych. Postępowanie badawcze powinno być interpretowane ostrożnie, ponieważ mimo rozwoju wiedzy naukowej nadal trudno poprawnie zdiagnozować na przyklad neurotyczny lęk (zmęczenie lub złość pacjenta może spowodować wzrost czynności bioelektrycznej w badaniu EEG - właściwej dla zapisu patologicznego).

Każdy wychowawca jest twórcą i jeśli mądrze kreuje - wprowadza w życie wartościowe, pomaga w holistycznym rozwoju wychowanka, „budując mosty, a nie bariery”, wyzwala, jak to ujął Erich Fromm, ,potencjał biofilny postawy

${ }^{25}$ W. Pasterniak, O celach edukacji literackiej, Goleniów 1991, s. 15-16.

${ }^{26}$ E. Wolter, Inwencje wychowawcze, Warszawa 2002, s. 27.

${ }^{27}$ Z. Pietrasiński (red.), Studenci o własnym rozwoju, Warszawa 1997, s. 97-109.

${ }^{28}$ K. Drat-Ruszczak, Twórczość w nauce, w: Filozofia a nauka zarys encyklopedyczny, Warszawa 1987, s. 732-740.

${ }^{29}$ L. Krzywicki, Przeszłość a teraźniejszość, w: E. Nowicka, M. Głowacka-Grajper (red.), dz. cyt., s. 98 .

${ }^{30} \mathrm{~K}$. Konarzewski, Jak uprawiać badania oświatowe. Metodologia praktyczna, Warszawa 2000, s. 22-23. 
być" - działa w imieniu wychowanka jako jego rzecznik i mądry przyjaciel ${ }^{31}$. Wychowanie podmiotowe jest procesem wspomagania i aktualizowania potencjalnych zdolności, osiagania subiektywnie odczuwanego dobrostanu osoby ${ }^{32}$. Podmiotowa samorealizacja poznawcza - emocjonalna - aplikacyjna jest zogniskowana na fundamencie wartości ${ }^{33}$ prawdy - dobra - piękna i może urzeczywistnić afirmację pełni człowieczeństwa w przedkładaniu hierarchii wartości „być” nad „mieć”.

Podmiotowo-holistyczna koncepcja człowieka ${ }^{34}$ jest wyjaśniana dzięki osiągnięciom badawczym nauk humanistycznych i nauk przyrodniczych (pedagogika holistyczna ${ }^{35}$ ), jest wpisana $\mathrm{w}$ uniwersalistyczny paradygmat jedności makrokosmosu-mikrokosmosu oraz roli sacrum ${ }^{36}$ środowiska biosfery, którego człowiek jako osoba - istota społeczna - jest integralną cząstką ${ }^{37}$. Stanowi także implikację idei zrównoważonego rozwoju ${ }^{38}$ - jako cywilizacji pokoju, edukacji ekologicznej $^{39}$ - której celem jest kształtowanie świadomości ekologicznej w zakresie kreowania równowagi dynamicznej związków człowieka z otoczeniem społeczno-przyrodniczym (homeostaza antropogeniczna). Wyraża się zdrowym stylem życia - samozachowaniem, samorozwojem, samotworzeniem (antokreacja ${ }^{40}$ ), wzniosłym sensem życia ${ }^{41}$, zgodnym z naturalnymi prawami przyrody i rozwoju społecznego.

${ }^{31}$ J. Tarnowski, Jan Pawet II w trzech wymiarach pedagogicznych, w: J. Placha, W. Sroczyński, E. Wolter (red.), dz. cyt., s. 15.

32 A. Cudowska, Samorealizacja $w$ perspektywie poszukiwań nowego idealu wychowania człowieka , globalnego”. Próba wpisywania znaczeń, w: J. Kojkoł, P. J. Przybysz (red.), Edukacja wobec wyzwań kulturowo-cywilizacyjnych, Gdynia 2002, s. 219.

${ }^{33}$ T. Pilch, Kryzys wartości - kryzys edukacji i wychowania, w: D. Waloszek (red.), Pedagogia Jana Pawła II wyzwaniem dla wspótczesnej myśli i teorii wychowania, Mysłowice 2008, s. 33-34.

${ }^{34}$ Z. Łyko, Poznaj samego siebie (studium filozoficzno-psychologiczno-teologiczne), w: Z. Dziubiński (red.), Drogi i bezdroża sportu i turystyki, Warszawa 2007, s. 57.

${ }^{35}$ D. Skulicz, Pedagogika a nauki medyczne, w: S. Palka (red.), Pogranicza pedagogiki i nauk pomocniczych, Kraków 2004, s. 71. Por. A. Szyszko-Bohusz, Pedagogika holistyczna wobec zmian w humanistyce, w: J. Gnitecki (red.), Teorie pedagogiczne wobec zmian w humanistyce i w otaczajacym świecie, Olsztyn-Poznań 2002, s. 42-43.

${ }^{36}$ J. Dębowski, Ekologia osoby ludzkiej w chrześcijańskim nauczaniu społecznym, Olsztyn 2001, s. $158-159$.

${ }^{37}$ J. M. Dołęga, Potrzeba nauk środowiskowych w polskiej edukacji XXI wieku, w: A. Karpińska, W. Wróblewska (red.), Pola poznawcze dydaktyki w dialogu i perspektywie, Białystok 2008, s. 136.

${ }^{38}$ E. Wolter, Pedagogiczne implikacje równoważenia rozwoju, „Zarządzanie i Edukacja” 50 (2007), s. 117n.

${ }^{39}$ E. Wolter, Historyczne aspekty..., s. 19-20.

${ }^{40}$ L. Turos, Autokreacja jako składnik filozofii życia XXI wieku, w: tenże (red.), Andragogika autokreacji, Warszawa 2007, s. 88.

${ }^{41}$ L. Michnowski, Ekohumanizm i trwały rozwój a koncepcja cywilizacji życia i miłości Jana Pawła II, w: A. Skowroński (red.), Rozmaitości ekofilozofii, Olecko 2006, s. 288. 
Wyjaśniając, uzasadniając problem podmiotowości jako kategorii pedagogicznej, przypomnę, iż edukację generują następujące procesy ${ }^{42}$ : globalizacja, etatyzacja, nacjonalizacja, kolektywizacja, polityzacja, socjalizacja, inkulturacja i personalizacja, wychowanie i jurydyfikacja, kształcenie i humanizacja, hominizacja. Przy czym edukacja pełni dwie podstawowe funkcje: socjalizacyjną oraz wyzwalająca od dominacji społecznej, środowiskowej (wykraczanie poza status quo). Natomiast jej związek z kulturą wyrażają przede wszystkim: progresywizm, esencjalizm, perenializm i rekonstrukcjonizm. Wartością pedagogiki jako dyscypliny naukowej jest poznanie prawdy - w obliczu godności osoby - w podmiotowej strukturze ,ja" - każde inne ,ja"43, ze względu na typy zaangażowań

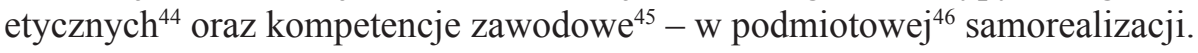

Podmiotami w szkolnym programie wychowawczym są: uczniowie, nauczyciele-wychowawcy, rodzice - w procesie wzajemnego oddziaływania ${ }^{47}$, autonomicznego dojrzewania do akceptacji, empatycznego rozumienia dzieci i młodzieży - w sensie personalistycznym ${ }^{48}$. Według doktryny personalistycznej, człowiek jako osoba jest istotą wolną i rozumna, zdolną do miłości i ponoszenia odpowiedzialności w kontaktach z innym ludźmi. Nauczyciele-wychowawcy w myśl założeń personalizmu muszą szanować godność i dostrzegać w wychowanku wartość naczelną; traktować ucznia podmiotowo, respektować jego prawo do szacunku, wyrażania myśli i uczuć ${ }^{49}$; nauczyć szacunku dla własnej godności zarówno w indywidualnym rozwoju, jak i w harmonijnym współistnieniu w grupie społecznej. Nauczyciele-wychowawcy według Jana Pawła II są twórcami, którzy „rodzą” w znaczeniu duchowym (rodzicielstwo duchowe ${ }^{50}$ ). Dojrzałe rodzicielstwo, także duchowe, rozumie młodość w metodologicznie złożonej eksplikacji prawdy o człowieku - w podmiotowej komunikacji za pomocą dialogu ${ }^{51}$

${ }^{42}$ B. Śliwerski, Edukacja, w: C. Rogowski (red.), dz. cyt., s. 132-133.

${ }^{43} \mathrm{~J}$. Michalski, Między etykq szczegółowq a uniwersalna, czyli co obowiqzuje wspótczesnego pedagoga, w: W. Sawczuk (red.), Po co etyka pedagogom?, Toruń 2007, s. 51.

${ }_{44}$ Zob. Z. Kwieciński, Pomiędzy autonomiq a zaangażowaniem - wprowadzenie do debaty, w: W. Sawczuk (red.), dz. cyt., s. 23.

${ }^{45}$ Zob. Z. Wiatrowski, Etyka zawodowa - ważny wyznacznik jakości działalności pedagogicz$n e j$, w: W. Sawczuk (red.), dz. cyt., s. 84-85.

${ }^{46} \mathrm{M}$. Nowak, Wychowanie etosu pracy $w$ programie wychowawczym szkoly wyższej, w: E. Konovaluk, M. Nowak (red.), Praca - etos - wychowanie, Biała Podlaska 2007, s. 208.

${ }^{47}$ Z. Struzik, Program wychowawczy oparty na wartościach, cz. 2, Warszawa Wilanów 2007, s. 10.

${ }^{48}$ Do najbardziej znanych przedstawicieli personalizmu należą: Max Scheller, Jacques Maritain, Etienne Gilson, Emanuel Mounier, Karol Wojtyła, Józef Tischner, Tadeusz Styczeń, Mieczysław Gogacz.

${ }^{49}$ M. Łobocki, Teoria wychowania w zarysie, Kraków 2007, s. 153-154.

${ }^{50}$ Cz. Drążek, J. Kawecki (red.), Dziecko w nauczaniu Jana Pawła II. Antologia wypowiedzi, Kraków 1986, s. 49-50.

${ }^{51}$ K. Denek, Konceptualizacja XV TSN „Edukacja jutra”, w: K. Denek, K. Zatoń, A. Kwaśna (red.), Edukacja jutra - XIV Tatrzańskie Seminarium Naukowe, Wrocław 2008, s. 339. 
wychowawczego, którego kulturowo ukształtowanym wzorem jest dialog sokratejski (protreptyka - elenktyka - maieutyka). Wychowanie podmiotowe w personalistycznym ujęciu służy nie tylko realizacji prakseologiczno-technologicznego modelu postępowania ${ }^{52}$ (celem jest efektywność), lecz przede wszystkim humanistycznemu, ukierunkowanemu na indywidualizację, autonomiczne typy zaangażowań etycznych, jakość ${ }^{53}$, zdrowy styl życia, konstruktywną samorealizację, podporządkowaniu wymiarom człowieczeństwa ${ }^{54}$ absolutów prawdy - dobra piękna.

\section{Subjectivity as a pedagogical category (Summary)}

The article aims at explaining subjectivity as one of the basic pedagogical categories of the post-modern society - taking into consideration the following criteria: subjectivity as a value, the party that brings up vs. the party that is brought up, the principle of subjectivity.

${ }^{52} \mathrm{~S}$. Palka, Modele procesu dydaktyczno-wychowawczego $w$ praktyce szkolnej a przystosowanie studentów do zawodu nauczycielskiego (zarys wstępny), w: T. Gumuła, T. Dyrda (red.), Ksztatcenie kandydatów na nauczycieli. Teoria - praktyka, Kielce 2006, s. 21-22. Por. S. Palka, Badawcze inspirowanie teorii i praktyki edukacyjnej, w: A. Karpińska, W. Wróblewska (red.), dz. cyt., s. 39-40.

53 D. Pyć, Prawo zrównoważonego rozwoju, Gdańsk 2006, s. 49.

${ }^{54}$ F. Znaniecki, Humanizm i poznanie i inne pisma filozoficzne, Warszawa 1991, s. 239. 